\title{
Experience in Patients with Penile Cancer
}

R Villagómez-Camargo ${ }^{1,2}$, ÁJ Montiel-Jarquín ${ }^{1,2}$, A Contreras-Díaz ${ }^{3}$, M Chopin-Gazga ${ }^{3}$, MS

Romero-Figueroa ${ }^{4}$, E García-Cano $^{1}, \mathrm{~J}_{\text {Loría-Castellanos }}{ }^{5}$, HA Solis-Mendoza ${ }^{1}$

\begin{abstract}
Objective: To describe the experience in 22 patients with penile cancer.

Methods: observational, cross-sectional study. There were included patients with complete medical records and histopathologic report of penile cancer during the period 2010-2013.

Results: The mean age was 64.95 years, evolution time to diagnosis was 25 months, $68.2 \%$ smoked and presented HPV infection, all had phimosis, $72.7 \%$ had pain in the penis and groin, $81.8 \%$ had palpable nodules and $45.5 \%$ lesions $>3 \mathrm{~cm} ; 86.3 \%$ were diagnosed with clinical stage IIIA and higher, $59.1 \%$ underwent partial penectomy, $86.4 \%$ were squamous cell variety, $40.9 \%$ of the patients died at 6 months post-surgery, $66.6 \%$ of smokers presented metastasis, all those positive for HPV infection and smoking had neurovascular invasion and died; $83.3 \%(n=6)$ that underwent partial penectomy and positive lymph node dissection with metastases died. Overall survival was $40.9 \%$ at 5 years and the average survival time was 41.8 months.
\end{abstract}

Conclusion: we conclude that penile cancer remains rare, which has a high mortality and the diagnosis is made late. Measures for the realization of a timely diagnosis are suggested this may improve the prognosis and the treatment time can be curative.

Keywords: Experience, penile cancer, treatment

From: ${ }^{1}$ High Specialty Medical Unit Hospital of Traumatology and Orthopedics of Puebla, Mexican Social Security Institute, Mexico. ${ }^{2}$ National Academy of Medical Education. ${ }^{3}$ Regional General Hospital number 36 in Puebla, Mexican Social Security Institute, Mexico. ${ }^{4}$ Western Mexico Delegation of the Mexican Social Security Institute, Mexico. ${ }^{5}$ Special Projects Division of the Mexican Social Security Institute, Mexico.

Correspondence: Dr A Montiel-Jarquín, High Speciality Medical Unit Hospital of Traumatology and Orthopedics of Puebla, (Division of Investigation), Mexican Social Security Institute. Diagonal Defensores de la República esquina 6 poniente s/n Colonia Amor, CP 72140, Puebla, México. E-mail: alvaro.montielj@imss.gob.mx or dralmoja@hotmail.com 


\section{INTRODUCTION}

Penile cancer is an infrequent neoplasia, representing 0.5 to $5 \%$ of all male malignancies. The incidence is variable, in Europe it is approximately 0.5 to 1.6 in 100,000 individuals and 0.7-0.9 in 100,000 in the USA. In Mexico in the Histopathological Registry of Malignant Neoplasms in the year of 2003, 346 cases were reported with an incidence of 0.91 in 100,000 and 0.31 of all malignancies in that year, while mortality ocurred in 103 cases (Mortality rate of 0.2 in 100,000 males), representing the $0.17 \%$ of deads due to cancer $(1,2)$.

It is more common in the sixth decade of life and the major risk factors are phimosis, poor hygiene and smoking. The presentation of penile cancer may vary greatly from forms of benign appearance to invasive carcinoma, which may prolong the time for the patient to seek medical care up to one year (1).

Habitully it presents as a small lesion, with a papillary or flat growth pattern, which extends slowly and gradually. The most common site of metastasis are the inguinal lymph nodes. The physical inguinal and genitalia exam is necessary for diagnosis, the confirmation of diagnosis is made by biopsy of suspicious lesions. The squamous cell carcinoma is the most frequent histological variant found in up to $95 \%$ of the cases. The staging system is the base for treatment, surgery is the most effective option for these patients. Due to the poor prognosis of penile cancer for life and function and its little incidence $(3,4)$. The objective of this paper is to present the experience in the management at three years of penile cancer. 


\section{SUBJECTS AND METHODS}

A cross-sectional study was conducted on patients with penile cancer attending a Second Level Medical Facility, General Regional Hospital No. 36 from Mexican Social Security Institute between March of 2010 and June of 2013. The patients had a complete medical record with a pathology report, the variables were: sociodemographic characteristics, risk factors, signs and symptoms, evolution from the time of diagnosis until the present, histologic variety, morphology, location, Tumor Nodule Metastasis (TNM) staging of the tumor, treatment performed and causes of death.

\section{Statistical analyses}

Descriptive statistics were used with measures of central tendency and dispersión, using the StatCalc for Mac program. All the patients were kept anonymous during the study.

\section{RESULTS}

There were included 22 patients, the average age was 64.95 (minimun 30 - maximum 93), \pm 14.14 years. Clinical characteristics and the histopathological results of patients are shown in TableS 1 and 2.

Four (18.2\%) patients had metastases by Computed Tomography (CT) scan, 2 (9.1\%) by CT scan and chest X-ray and $16(72.7 \%)$ had no evidence of metastases on CT scan or chest Xray. One (4.5) patient underwent extended circumcision, 5 (22.7\%) partial penectomy, 8 (36.4\%) partial penectomy with inguinal disection, 1 (4.5\%) radical penectomy and inguinal dissection, 2 $(9.1 \%)$ total penectomy and $5(2.7 \%)$ total penectomy and inguinal dissection. At the time of the study $13(59.1 \%)$ patients were alive, the reason for the death of the other patients was 
abdominal metastases in $1(4.5 \%)$ patient, lung metastases in $7(31.8 \%)$ and $1(4.5 \%)$ due to Fournier's syndrome. Of the patients having relevant medical history $=$ smoking, Human Papylloma Virus (HPV) and smoking plus HPV, it was found that $5(83.3 \%, n=6)$ had lesions greater than $5 \mathrm{~cm}$; the smokers patients with positive HPV were four $(25 \%, \mathrm{n}=16)$ none of them had evidence of metastasis.

Four patients presented a clinical stage IV [57.14\% of the smokers and two $(28.57 \%)$ of smokers with positive HPV $n=7]$. Tissue invasion was presented in five patients smokers and HPV positive $(38.46 \%, \mathrm{n}=13)$. The greatest cause of death was lung metastasis in 6 patients smokers and HPV positive $(85.71 \%, \mathrm{n}=7)$. Details are shown in table 3 .

The overall survival at 5 years was $40.9 \%$ and the average survival time was 41.8 months. (Table 4, Figure 1).

\section{DISCUSSION}

Penile cancer is a rare disease (1). The incidence in men younger than 40 years old is $19 \%$ and $7 \%$ for men younger than 30 years old. Our patients showed a mean of 65 years, according with the world literature which describes that penile cancer occurs in men over 50 years old (2).

The average development time from onset of the injury until the diagnosis was 25 months. According with Lont AP et al who mentioned that the time of evolution since the appearance of lesions until the time of diagnosis is more than 12 months (5). Madsen BS et al described an intact foreskin in $25-60 \%$ of penile cancer patients (6).

These findings differ with our study, because we found an intact foreskin in all our patients. The major medical background in the studied patients were; smoking and HPV 
infection. Fifteen patients $(68.18 \%)$ presented some or the association of these two factors, the literature describes that smoking increases the risk of 3 to 4.5 times $(5,7-9)$.

The clinical presentation varies, from a lesion with induration to an exophytic lesion, causing itching, burning in the foreskin and presence of an ulceration of the glans or the foreskin. Pain is less frequent, however, in this study the most frequent reason for consultation was the presence of a penile lesion, asymptomatic in $27.3 \%$, with pain in the penis, groin and loss weight in $9.1 \%$. The $22.7 \%$ showed groin pain, the $27.3 \%$ presented pain in the groin and penis, the 9.1\% with only penis pain and the $4.5 \%$ showed inguinal pain and loss weigth (9-11).

Burgers $\mathrm{JK}$, et al mentioned that the presentation of the lesion is more frequent on the glans (48\%), in the foreskin in $21 \%$ and on the glans and foreskin in $9 \%$, in the coronal sulcus in $6 \%$ and in the body of the penis in less than $2 \%(9)$.

The patients delay medical treatment and refer injuries with more than one year of appearance before the diagnosis. In this study in $40.9 \%$ of the patients, the lesion was presented in the foreskin and glans, in $40.9 \%$ covered to the distal third of the penis; which is an unusual data in the literature, even though the time of evolution in these patients was similar to that reported in the literature (12 months) $(1,8,10-14)$.

All of the smoking patients with HPV presented neurovascular invasion. In the reviewed literature we did not find any association between these factors and penile cancer $(1,15-20)$.

However, more prospectives and longitudinal studies are required to determine whether these factors are related or not. The patients with lesions larger than $5 \mathrm{~cm}(83.3 \%$, $\mathrm{n}=6)$ were smokers and some of them had association with HPV. Besides, 66.6\% of the smokers had metastases at diagnosis and were also in advanced clinical stage. In the literature review we did not find any association with this factors $(15-21)$. The squamous cell carcinoma is the most 
frequent $(48-65 \%)$. In this study the $86.4 \%$ were squamous cell variety, other varieties were verrucous in $9.1 \%$ and sarcomatoid in $4.5 \%$. It is mentioned that the sarcomatoid variety is very aggressive $(1,9,11,22-24)$. However, $4.5 \%(n=1)$ of patients with this variety were alive at the time of data collection.

All the patients with metastasis $(n=6)$ were smokers and HPV positive, and all of the patients with a IV clinical stage $(n=7)$ also had this background. The $75 \%(n=16)$ of patients with tissue invasion by histopathology were smokers and/or had HPV infection. The $85.71 \%(n=7)$ of the patients who died from lung metastases were also smokers. In the literature review we did not find any association between penile cancer and morbidity and mortality, but with the development of the disease $(25-30)$.

Overall survival was $40.9 \%$ at 5 years and the average survival time was 41.818 months, which is similar to that reported in the world literatura $(25,30)$. Due to the type of study, no measures of association between penile cancer and these factors were performed.

\section{CONCLUSION}

The penile cancer is a rare disease with high mortality with a late diagnosis. Measures to perform an early diagnosis are suggested and therefore improve prognosis, since treatment can be curative.

\section{ACKNOWLEDGEMENTS}

This study has not received funding. 


\section{AUTHORS' NOTE}

R Villagómez-Camargo and AJ Montiel-Jarquín conceived paper, conducted data analysis wrote manuscript and approved final version. A Contreras-Díaz oversaw data collection. M ChopinGazga and MS Romero-Figueroa participated in study design, data analysis and interpretation and approved the final version.

E García-Cano, partipated in data analysis, critically revised manuscript and approved final version. J Loría-Castellanos and HA Solis-Mendoza participated in study design, revision of the manuscript and approved final version.

All authors declare that they have no conflicts of interest. 


\section{REFERENCES}

1. Villagómez Camargo R. "Experiencia en el manejo del Cáncer de pene en el Hospital General Regional No. 36 del Instituto Mexicano del Seguro Social. Tesis de Especialidad. UPAEP-IMSS 2014.

2. Lynch DFJ, Pettaway C, Lynch D, Davis D. Tumors of the penis. En: Wein AJ, Kavoussi LR, Novick AC, et al., (eds.) Campbell-Walsh Urology Tenth Edition. 2011: 959-992.

3. Pow-Sang MR, Ferreria U, Pow-Sang J, Nardi A, Destefano V. Epidemiology and natural history of penile cancer. Urology 2010; 76 (Suppl 2A): S2-6.

4. Jiménez M., Solares M., Martínez P., Martínez J., Hinojosa J., Zamora J., Rivera L. Cáncer de pene. Cancerología 2011; 6: 7-11.

5. Lont AP, Kroon BK, Horenblas S. Presence of high-risk human papillomavirus DNA in penile carcinoma predicts favorable outcome in survival. Int J Cancer 2006; 119: 107881.

6. Madsen BS, van den Brule AJ, Jensen HL. Risk factors for squamous cell carcinoma of the penis-population-based case-control study in Denmark. Cancer Epidemiol Biomarkers Prev 2008; 17: 2683-91.

7. The National Comprehensive Cancer Network. Guidelines Penile Cancer Inc. 2012. Version 1.2012.

8. Misra S, Chaturvedi A., Misra NC. Penile carcinoma: a challenge for the developing world. Lancet Oncol 2004; 5: 240-7.

9. Burgers JK, Badalament RA., Drago JR. Penile cancer: clinical presentation, diagnosis, and staging. Urol Clin North Am 1992; 19: 247-56. 
10. Cubilla AL, Reuter V, Velazquez E, Piris A, Saito S, Young RH. Histologic classification of penile carcinoma and its relation to outcome in 61 patients with primary resection. Int $\mathrm{J}$ Surg Pathol 2001; 9: 111-20.

11. Novara G1, Galfano A, De Marco V, Artibani W, Ficarra V. Prognostic factors in squamous cell carcinoma of the penis. Nat Clin Pract Urol 2007; 4: 140-6.

12. Eble JN, Sauter G, Epstein JI, Sesterhenn IA. World Health Organization Classification of Tumours: Pathology and Genetics of Tumours of the Urinary System and Male Genital Organs. Lyon: IARC Publishing; 2004: 281-90.

13. Chaux A, Lezcano C, Cubilla AL, Tamboli P, Ro J, Ayala A. Comparison of subtypes of penile squamous cell carcinoma from high and low incidence geographical regions. Int $\mathrm{J}$ Surg Pathol 2010; 18: 268-77.

14. Chaux A, Velazquez EF, Algaba F, Ayala G, Cubilla AL. Developments in the pathology of penile squeamous cell carcinomas. Urology 2010; 76: S7-S14.

15. Leijte JA1, Kirrander P, Antonini N, Windahl T, Horenblas S. Recurrence patterns of squamous cell carcinoma of the penis: recommendations for follow-up based on a twocentre analysis of 700 patients. Eur Urol 2008; 54: 161-8.

16. Pandey D1, Mahajan V, Kannan RR. Prognostic factors in node-positive carcinoma of the penis. J Surg Oncol 2006; 93: 133-8.

17. Broders AC. Squamous-cell epithelioma of the skin: a study of 256 cases. Ann Surg 1921; 73: 141-60.

18. Solsona E, Bahl A, Brandes SB, Dickerson D, Puras-Baez A, van Poppel H, Watkin NA. New developments in the treatment of localized penile cancer. Urology 2010; 76: S3642. 
19. Bissada NK, Yakout HH, Fahmy WE, Gayed MS, Touijer AK, Greene GF, et al. Multiinstitutional long-term experience with conservative surgery for invasive penile carcinoma. J Urol 2003; 169: 500-2.

20. Lont AP, Gallee MP, Meinhardt W, van Tinteren H, Horenblas S. Penis conserving treatment for $\mathrm{T} 1$ and $\mathrm{T} 2$ penile carcinoma: clinical implications of a local recurrence. $\mathrm{J}$ Urol 2006; 176: 575-80.

21. Smith Y, Hadway P, Ahmed S, Perry MJ, Corbishley CM, Watkin NA. Penile preserving surgery for male distal urethral carcinoma. BJU Int 2007; 100: 82-7.

22. Korets R, Koppie TM, Snyder ME, Russo P. Partial penectomy for patients with squamous cell carcinoma of the penis: the Memorial Sloan-Kettering experience. Ann Surg Oncol 2007; 14: 3614-9.

23. Ficarra V, Akduman B, Bouchot O, Palou J, Tobias-Machado M. Prognostic factors in penile cancer. Urology 2010; 76: S66-S73.

24. Lont AP, Besnard AP, Gallee MP, van Tinteren H, Horenblas S. A comparison of physical examination and imaging in determining the extent of primary penile carcinoma. BJU Int 2003; 91: 493-5.

25. Tabatabaei S, McDougal WS. Invasive carcinoma of the penis: management and prognosis. En: Ritchie JP, D'Amico AV, eds. Urologic Oncology; 2005: 710-22.

26. Pietrzak P, Corbishley C, Watkin N. Organ-sparing surgery for invasive penile cancer: early follow-up data. BJU Int 2004; 94: 1253-7.

27. Shindel AW, Mann MW, Lev RY, Sengelmann R, Petersen J, Hruza GJ et al. Mohs micrographic surgery for penile cancer: management and long-term follow up. J Urol 2007; 178: 1980-5. 
28. Horenblas S, Van Tinteren H, Delemarre JF, Moonen LM, Lustig V, Kröger R. Squamous cell carcinoma of the penis: accuracy of tumor, nodes and metástasis classification system, and role of lymphangiography, computerized tomography scan. J Urol 1991; 146: 1279-83.

29. Scardino E, Villa G, Bonomo G, Matei DV, Verweij F, Rocco B et al. Magnetic resonance imaging combined with artificial erection for local staging of penile cancer. Urology 2004; 63: 1158-62.

30. Minhas S, Kayes O, Hegarty P, Kumar P, Freeman A, Ralph D. What surgical resection margins are required to achieve oncological control in men with primary penile cancer? BJU Int 2005; 96: 1040-3. 
Table 1: Clinical data series

\begin{tabular}{lrc}
\hline Tumor size & S (\%) \\
\hline & & \\
$<\mathbf{1} \mathbf{~ c m}$ & 4 & 18.2 \\
$\mathbf{1 - 2} \mathbf{~ c m}$ & 8 & 36.4 \\
$\mathbf{3 - 4} \mathbf{~ c m}$ & 4 & 18.2 \\
$>\mathbf{5 c m}$ & 6 & 27.3 \\
Location & & \\
Foreskin & 1 & 4.5 \\
Foreskin and glans & 9 & 40.9 \\
Distal third of the penis & 9 & 40.9 \\
Middle third of the penis & 1 & 4.5 \\
Proximal third of the penis & 1 & 4.5 \\
Entire penis & 1 & 4.5 \\
Type of lesion & & \\
Exofitic & 3 & 59.1 \\
Flat & 2 & 9.1 \\
Ulcerated & 3 & 13.6 \\
Warty & 4 & 18.2 \\
Clinical picture & & \\
Asymptomatic & 6 & 27.3 \\
Pain in the lesion & 2 & 9.1 \\
Inguinal pain & 5 & 22.7 \\
Pain in the lesion and inguinal & 6 & 27.3 \\
region & & \\
Inguinal pain and weight loss & 1 & 4.5 \\
Pain in the lesion and inguinal & 2 & 9.1 \\
region, and weight loss & & \\
Background & & \\
Phimosis & 22 & 100 \\
Smoking & 6 & 27.3 \\
HPV & 4 & 18.2 \\
Smoking and HPV & 5 & 22.7 \\
\hline & & \\
\hline
\end{tabular}

Abbreviations: $\mathrm{s}=$ sample, $\%=$ percentage, $<=$ minor, $>$ major, $\mathrm{cm}=$ centimeter, $\mathrm{HPV}=\mathrm{Human}$ papylloma virus. 
Table 2: Pathological features

\begin{tabular}{lrc}
\hline Tumor & S (\%) \\
\hline & & \\
Ta & 1 & 4.5 \\
T1 a & 2 & 9,1 \\
T1b & 1 & 4.5 \\
T2 & 9 & 40.9 \\
T3 & 8 & 36.4 \\
T4 & 1 & 4.5 \\
Inguinal lymph & & \\
cN0 & 4 & 18.2 \\
cN1 & 7 & 31.8 \\
cN2 & 9 & 40.9 \\
cN3 & 2 & 9.1 \\
Metastasis & & \\
M0 & 16 & 72.7 \\
M1 & 6 & 27.3 \\
Clinical Stage & & \\
I & 1 & 4.5 \\
II & 2 & 9.2 \\
IIIa & 7 & 31.8 \\
IIIb & 5 & 22.7 \\
IV & 7 & 31.8 \\
Histological grade & & \\
G1 & 8 & 35.4 \\
G2 & 9 & 40.9 \\
G3 & 5 & 22.7 \\
Kind of invasion & & \\
Neural invasion & 3 & 13.6 \\
Neural and & & \\
invasion & 13 & 59.1 \\
No invasion & 6 & 27.3 \\
\hline Abbreviations: s=sample, \%=percentage \\
\end{tabular}


Table 3: Clinical, histopathologic conditions, and cause of death of the patients at the time of the study.

\begin{tabular}{|c|c|c|c|c|c|c|}
\hline Patient condition & & $\begin{array}{l}\text { Smoki } \\
\text { ng }\end{array}$ & $\begin{array}{l}\text { HP } \\
\text { V }\end{array}$ & $\begin{array}{l}\text { Smoking } \\
+ \text { HPV }\end{array}$ & $\begin{array}{l}\text { No } \\
\text { background }\end{array}$ & $s$ \\
\hline \multirow{7}{*}{ Clinical stage } & Stage I & 0 & 1 & 0 & 0 & 1 \\
\hline & Stage II & 1 & 0 & 0 & 1 & 2 \\
\hline & Stage IIIa & 1 & 1 & 2 & 3 & 7 \\
\hline & Stage IIIb & 0 & 1 & 1 & 3 & 5 \\
\hline & Stage IV & 4 & 1 & 2 & 0 & 7 \\
\hline & & 6 & 4 & 5 & 7 & 22 \\
\hline & $<1 \mathrm{~cm}$ & 0 & 0 & 2 & 2 & 4 \\
\hline \multirow{4}{*}{ Lesion size: } & $1-2 \mathrm{~cm}$ & 2 & 3 & 2 & 1 & 8 \\
\hline & $3-4 \mathrm{~cm}$ & 1 & 0 & 0 & 3 & 4 \\
\hline & $>5 \mathrm{~cm}$ & 3 & 1 & 1 & 1 & 6 \\
\hline & & 6 & 4 & 5 & 7 & 22 \\
\hline \multirow{4}{*}{ Tissue invasion } & Neural & 1 & 0 & 0 & 2 & 3 \\
\hline & Neural and vascular & 3 & 3 & 5 & 2 & 13 \\
\hline & No invasión & 2 & 1 & 0 & 3 & 6 \\
\hline & & 6 & 4 & 5 & 7 & 22 \\
\hline \multirow{4}{*}{$\begin{array}{l}\text { Positive } \\
\text { metastasis }\end{array}$} & CT scan & 3 & 1 & 0 & 0 & 4 \\
\hline & CT scan + Chest X-ray & 1 & 0 & 1 & 0 & 2 \\
\hline & No evidence & 2 & 3 & 4 & 7 & 16 \\
\hline & & 6 & 4 & 5 & 7 & 22 \\
\hline \multirow{5}{*}{ Cause of death } & Alive & 3 & 4 & 0 & 6 & 13 \\
\hline & Lung Metastasis & 3 & 0 & 3 & 1 & 7 \\
\hline & Abdominal & 0 & 0 & 1 & 0 & 1 \\
\hline & Metastasis & 0 & 0 & 1 & 0 & 1 \\
\hline & Fournier syndrome & 6 & 4 & 5 & 7 & 22 \\
\hline
\end{tabular}

Abbreviations: $\mathrm{HPV}=$ human papylomma virus, $+=$ plus, $\mathrm{s}=$ sample, $<=$ less than, $>=$ greater than, CT scan=Computerized tomography scan. 
Table 4: Global survival time in penile cancer patients (Follow-up to 60 months)

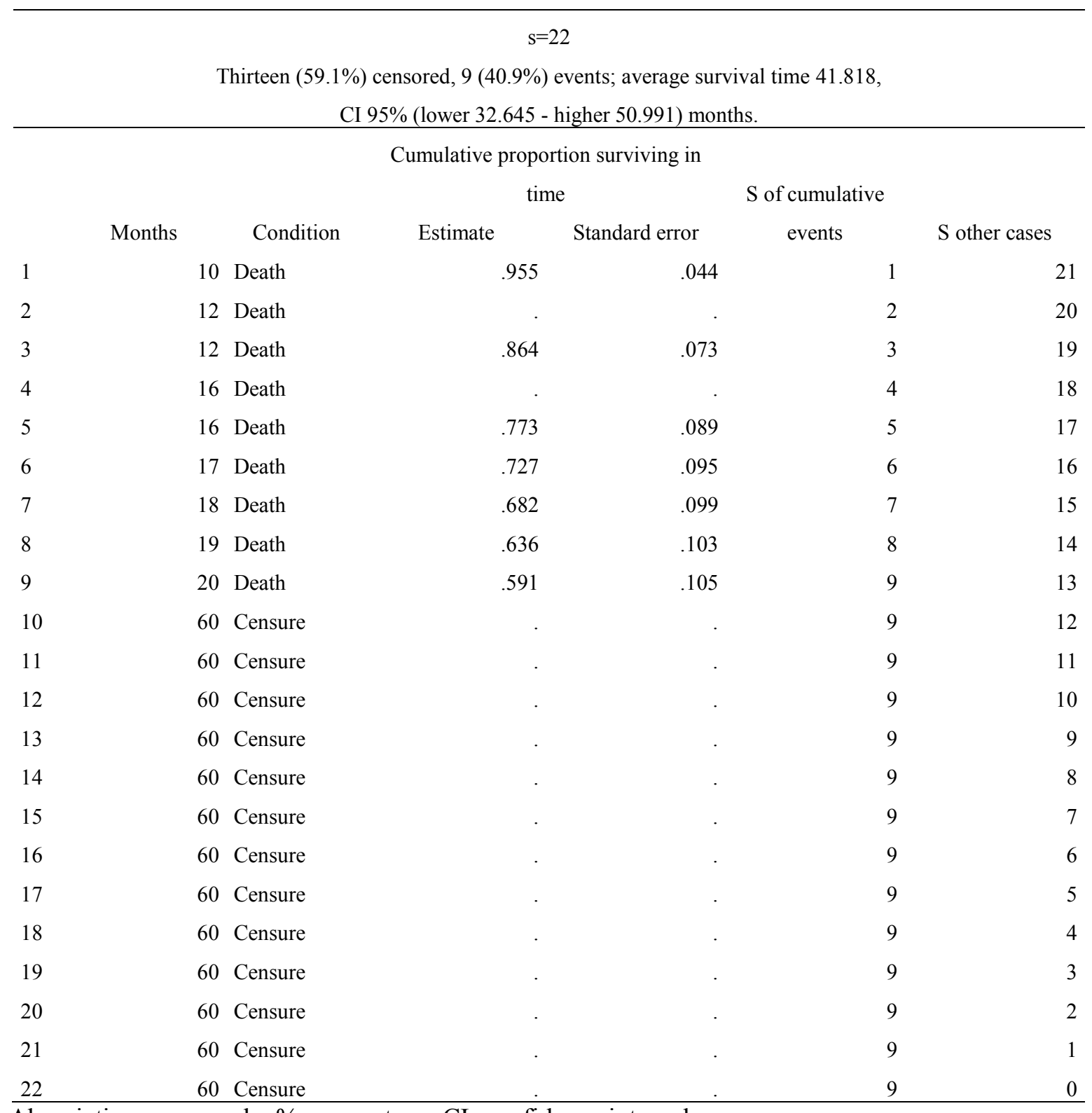

Abreviations: $\mathrm{s}=$ sample, $\%=$ percentage, $\mathrm{CI}=$ confidence interval. 


\section{Experience in Penile Cancer}

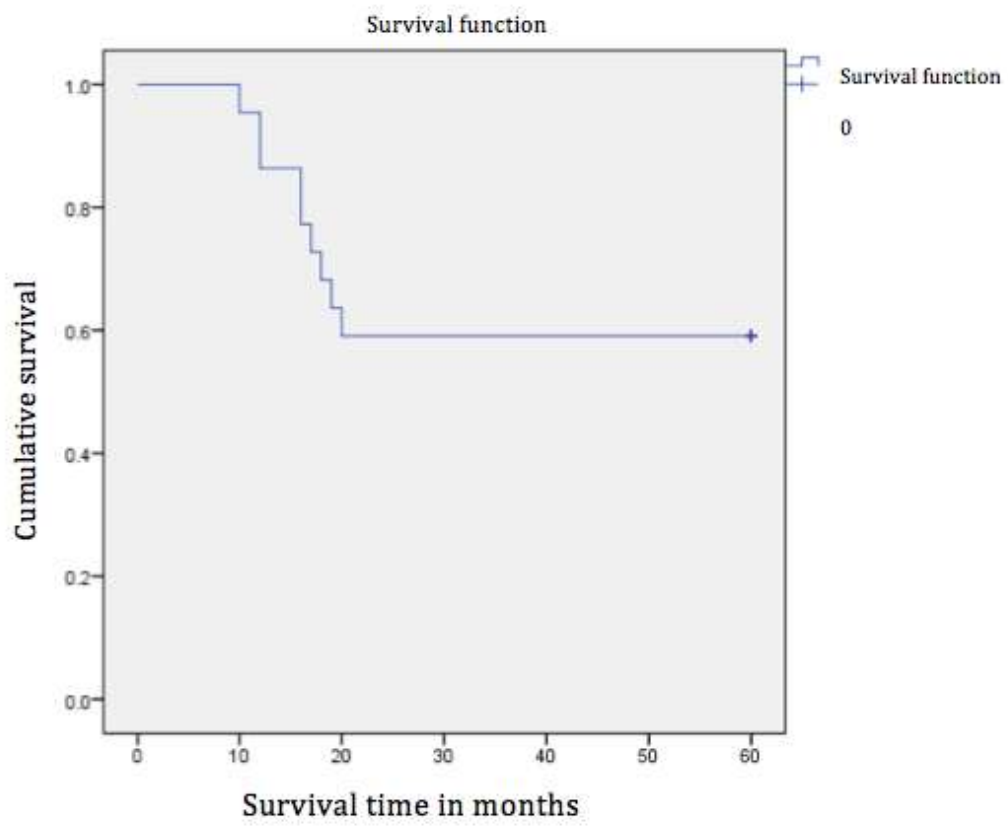

Figure: Overall survival at 60 months of penile cancer patients in all clinical stages 